\title{
Leptin and Vascular Cell Adhesion Protein 1 as Physiological Biomarkers in Serum of Women Suffering from Rheumatoid Arthritis
}

\author{
Faris Kata ${ }^{1 *} \mathbb{D}$, Saad W. Alsulaitti ${ }^{2}$, Muneera M. Adlan ${ }^{1}$ \\ ${ }^{1}$ Department of Biology, College of Education for Pure Science, University of Basrah, Basrah, Iraq; ${ }^{2}$ Basrah General Hospital, \\ Basrah Health Directorate, Ministry of Healthy, Basrah, Iraq
}

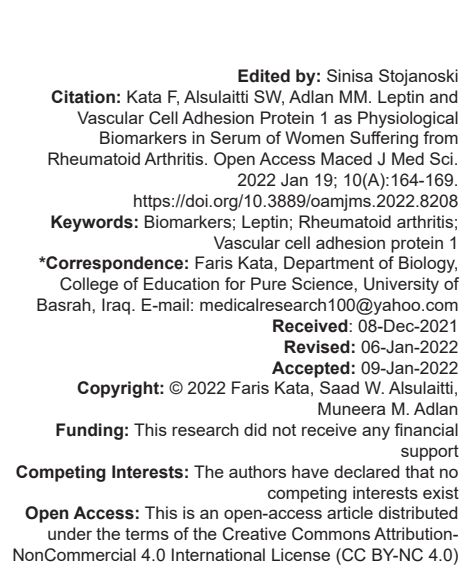

Introduction

Rheumatoid arthritis is defining as a common chronic and inflammatory disorder of systematic autoimmune disease, affecting about $1 \%$ of the total population in the world [1]. Although the causes of the disease are unknown, many potential causes that led to the emergence of this disease have been detecting. Those causes are mostly related to oxidative stress, genetic and hormonal factors, viral and bacterial factors, and environmental triggers [2]. Rheumatoid arthritis is a general health condition and the most dangerous chronic disease due to its complications in the various body systems, including muscular and blood systems. It influences the eyes, heart, blood vessels, respiratory, and urinary systems of millions of people throughout the world and thus leads to increased costs of healthcare [3].

Leptin is a small peptide hormone having a molecular weight of $16 \mathrm{KDa}$. It contains 167 amino acids and its composition is similar to many cytokines with helical chains such as Interleukin (IL-6), IL-11, and IL-12. It represents a member of the Adipokines family, which consists of several compounds involved in the inflammatory and immunomodulators processes[4].
Leptin functions as an immunomodulator in the human body. It has been observing that there is an increased incidence of serious infection in people suffering from Genetic Leptin Insufficiency, and through immune deficiency during malnutrition and starvation when the concentration of leptin level is low [5]. Leptin contributes to autoimmune diseases, as is the case with rheumatoid arthritis. However, its role is still unclear because in many studies it has been proclaims that the circulation of leptin levels in the blood has been detected as either high or unmodified compared to leptin levels in the healthy group [6], [7]. The Vascular Cell Adhesion Protein 1 (VCAM-1) is a glycoprotein combined with a surfactant Sialoglycoprotein whose molecular weight is $110 \mathrm{KDa}$ which belongs to the Immunoglobulin gene Superfamily and is one of the largest and most miscellaneous hosts of protein [8], [9]. The VCAM-1 adhesion molecule is mainly produce by endothelial cells, chondrocytes and synovial fibroblasts [10].

Due to the widespread adhesion molecules in human tissues and organs, participates in many physiological and pathological conditions such as autoimmune diseases, cardiovascular diseases, and inflammations [11]. The VCAM-1 adhesion molecule contributes importantly to the adhesion of cells with the 
vascular endothelial tissue and their migration through it, and thus it causes the spread of cancer cells over new sites [12]. Likewise, the VCAM-1 takes part in the adhesion of leukocytes with the vascular endothelial tissue at the site of inflammation. In addition, it serves to transmit the signal between endothelial cells and white blood cells and contributes importantly to the development of rheumatism and arteriosclerosis [13].

The VCAM-1 adhesion molecule is closely associate with the process of generating new blood vessels (angiogenesis) in the tumor and metastasis. This process known to be governed by numerous factors like epidermal growth factor, vascular endothelial growth factor (VEGF), angiopoietin factor, hepatocyte growth factor, and others [14]. Ding et al. observed that tissues containing high concentrations of VCAM-1 have a higher vascular density than tissues with low VCAM-1 levels in patients suffering from gastric cancer [15]. The present study aims to shed light on the physiological relationship between leptin, VCAM-1 biomarkers, and arthritis disease.

\section{Materials and Methods}

Fifty-six samples of blood serum were obtains from women having rheumatoid arthritis. The samples were divide based on age groups into 18 blood serum samples for women aged between 20 and 35 years, 19 blood serum samples for women between the ages of 35 and 50 years, and 19 blood serum samples for women whose ages range from 50 to 65 years. Samples were obtains from the patients who attended the joint consultation at Basrah general hospital and some private clinics.

The healthy group: 24 samples of blood serum were obtains from healthy women after making sure that they did not have rheumatoid arthritis. The samples were dividing into three age groups corresponding to the age groups of patients, with an amount of 8 samples for each age group.

Preparation of serum: A $5 \mathrm{~mL}$ of venous blood was obtained from the elbow by a clean medical syringe, and then the blood was place in a special gel tube and left for $20 \mathrm{~min}$. Afterward, it was incubated in a centrifuge for $15 \mathrm{~min}$ at a rate $3000 \mathrm{rpm}$ to obtain blood serum. The blood serum was dividing and placed in $1.5 \mathrm{~mL}$ Eppendorf tubes, and the samples were keeping in storage at $-80^{\circ} \mathrm{C}$ in deep freeze until the tests were carrying out.

The leptin and the VCAM-1 concentration was identifying by the Enzyme-Linked ImmunoSorbent Assay using the kits supplied by the American company of MyBioSource, and according to the method developed by (Jhon, 2000) [16] in measuring biomarker concentrations, the Sandwich technology, and the absorbance readings at a wavelength of $450 \mathrm{~nm}$.

The statistical analysis of the values resulting from the data was performs by adopting the t-test and using the OneWay ANOVA analysis. The significance between the averages was assesses through the Least Significant Difference test at $p<0.05$ and within the Standard Division using SPSS Ver. 21.

\section{Results}

The findings reported that there were no significant variances in the concentration of leptin hormone in rheumatoid arthritis (4440.80 Pg/mL) compared to the healthy group (4379.62 Pg/mL). Moreover, the statistical analysis did not reveal a significant variance in the leptin hormone concentration between the different age groups, the period, and the severity of the disease in rheumatoid arthritis patients, as shown in Table 1. Concerning VCAM-1 concentration, the findings of the present study reported that the concentration of VCAM-1 increased significantly in the patients' group having rheumatoid arthritis $(18.12 \mathrm{Pg} / \mathrm{mL})$ compared with the healthy group (11.75 Pg/mL). Moreover, the results, according to the age groups of patients, showed also significant differences between the three age groups, as the rate in the first age group was (16.50 Pg/mL \pm 2.74$)$, and in the second age group was $(18.84 \mathrm{Pg} / \mathrm{mL} \pm 3.27)$. The rate in the third age group was $19.21 \mathrm{Pg} / \mathrm{mL} \pm 2.76$. The different letters $(a, b)$ indicate that there were significant differences between the groups at $(p<0.05)$. However, the duration and severity of the disease did not show any significant effect on the level of the VCAM-1 biomarker in rheumatoid arthritis patients, as shown in Table 2.

Table 1: Concentration of leptin hormone

\begin{tabular}{|c|c|c|c|}
\hline Variables & No. & Mean \pm SD pg./mL & $p$ value \\
\hline \multicolumn{4}{|l|}{ Participants } \\
\hline RA & 56 & $4440.8 \pm 468.9$ & \multirow[t]{2}{*}{0.607} \\
\hline Healthy people & 24 & $4379.62 \pm 521.36$ & \\
\hline \multicolumn{4}{|l|}{ Age (years) } \\
\hline $20-35$ & 18 & $4442.5^{\mathrm{a}} \pm 824.12$ & \multirow[t]{3}{*}{ ns } \\
\hline $35-50$ & 19 & $4412.63^{\mathrm{a}} \pm 617.76$ & \\
\hline $50-65$ & 19 & $4467.36^{\mathrm{a}} \pm 804.66$ & \\
\hline \multicolumn{4}{|c|}{ The period of the disease } \\
\hline 1 month-3 years & 26 & $4494.65 \pm 609.6$ & \multirow[t]{2}{*}{0.516} \\
\hline 3 years -20 years & 30 & $4394.13 \pm 539.78$ & \\
\hline \multicolumn{4}{|l|}{ Severity } \\
\hline Severe & 16 & $4026.25^{a} \pm 1018.88$ & \multirow[t]{3}{*}{ ns } \\
\hline Moderate & 32 & $4685.5^{\mathrm{a}} \pm 494.12$ & \\
\hline Mild & 8 & $4291.12^{\mathrm{a}} \pm 549.38$ & \\
\hline
\end{tabular}

\section{Discussion}

Leptin is known for its pro-inflammatory activity which is performed by activating monocytes and 
Table 2: Concentration of VCAM-1

\begin{tabular}{|c|c|c|c|}
\hline Variables & No. & Mean \pm SD pg./mL & $\mathrm{p}$ value \\
\hline \multicolumn{4}{|l|}{ Participants } \\
\hline RA & 56 & $18.12 \pm 3.20$ & \multirow[t]{2}{*}{0.0001} \\
\hline Healthy people & 24 & $11.75 \pm 3.42$ & \\
\hline \multicolumn{4}{|l|}{ Age (years) } \\
\hline $20-35$ & 18 & $16.50^{\mathrm{a}} \pm 2.74$ & \multirow[t]{3}{*}{ ns } \\
\hline $35-50$ & 19 & $18.84^{b} \pm 3.27$ & \\
\hline $50-65$ & 19 & $19.21^{b} \pm 2.76$ & \\
\hline \multicolumn{4}{|c|}{ The period of the disease } \\
\hline 1 month- 3 years & 26 & $17.76 \pm 2.47$ & \multirow[t]{2}{*}{0.444} \\
\hline 3 years -20 years & 30 & $18.43 \pm 3.73$ & \\
\hline \multicolumn{4}{|l|}{ Severity } \\
\hline Severe & 16 & $17.50^{\mathrm{a}} \pm 4.14$ & \multirow[t]{3}{*}{ ns } \\
\hline Moderate & 32 & $18.56^{\mathrm{a}} \pm 2.90$ & \\
\hline Mild & 8 & $17.62^{\mathrm{a}} \pm 2.06$ & \\
\hline
\end{tabular}

macrophages to generate more inflammatory cytokines (such as IL-6 and Tumor Necrosis Factor [TNF $\alpha$ ]) [17]. Due to this effect generated by leptin, the concentrations of the leptin serum in rheumatoid patients are expecting to increase, which is inconsistent with what we have observed from the results of our current study [18].

The deficiency of genetic leptin increases the severity of inflammatory infections in humans. It has been proven that there are many severe infections in rheumatism patients in comparison with general people, particularly patients who are recipients of antitumor necrosis factor (anti-TNF) treatment. This indicates that leptin concentration is suppressing by chronic inflammation, which may contribute to an increased incidence in rheumatic patients [19].

The results of the current study investigating women with rheumatoid arthritis showed no significant differences in leptin concentration in the serum of patients and healthy people. In addition, the results of our study agreed with the findings of several other studies which reported that leptin concentrations in both patients and healthy subjects were similar [20], [21]. The reason can be ascribed to the fact that the patients did not receive Methotrexate (MTX) treatment, since this treatment stimulates the hypothalamus to produce leptin in patients. This has been confirming by an earlier study conducted by Bokarewa et al. which reported a significant rise in the level of leptin in the patients' serum, who are treated by MTX, compared with untreated patients [22].

Information - gained from various studies about the contribution of leptin to rheumatoid arthritis and other rheumatic diseases are incongruous. The findings are agreeing with many other studies such as Targońska-Stepniak et al. [23], Toussirot et al. [24], have shown leptin concentrations are similar in the serum of patients and the serum of healthy people. However, the results obtained from another study [25], have reported either lower leptin concentrations in patients' serum in comparison with healthy people, or high leptin concentrations in patients' serum compared with healthy people, as observed by many studies exploring patients with rheumatism and osteoporosis [17], [26]. The reason can be ascribed to a range of factors. These factors include the large proportion of rheumatism patients whose inflammatory parameters were not high at the time of examination. The higher BMI of the patient group compared with healthy people. The patients being in the period of chronic inflammation, as it has been report that leptin levels increase during acute inflammation and do not increase during chronic inflammation in various inflammatory diseases [27], [28].

The other goal of our research is to evaluate the relationship between leptin concentration in patients' serum according to age, duration, and severity of the disease. Our study did not report significant differences among leptin concentrations concerning these three variables. The results of our study agreed with the results of several studies [28], [29], while a study by Bokarewa et al. [22], have observed that leptin concentration gradually increased in the serum along with the progressive duration of the disease.

As for VCAM-1, VCAM-1 is considered an essential molecule of adhesion that assists the connection and link of white blood cells with each other or with other tissues, and then their transmission through the endothelial tissue. Thus, it has a significant role in pathological and physiological processes, including increasing the density of white blood cells and vascular cells, immune cell differentiation, invasion, and metastasis of tumor, transduction of intracellular signal and autoimmune diseases [30], [31]. As a chronic inflammatory disease, rheumatoid arthritis can be linked to an elevated level of this adhesion molecule. However, studies exploring changes in VCAM-1 levels and their connection with developing rheumatism are still scaring ]32[.

Our study's results reported that the concentration of VCAM-1 increased significantly among patients and healthy people. Our results agreed with earlier studies [33], [34], which confirmed a raise in the adhesion molecules levels in the patient's serum and that the adhesion molecules contribute importantly to developing rheumatism.

In his study, Wang et al. [35], observed a rise in levels of VCAM- 1 in the rheumatoid patients' serum, and that this raise persisted for a short period while patients were under conventional treatment. He also noted that some clinical symptoms decreased with the continuation of treatment, and then the levels of Rheumatoid Factors (RFs) decreased in the serum. Their decrease was accompanying by the gradual decreases of adhesion molecules, indicating the association of VCAM-1 with the disease status and levels of RFs. Similarly, Klimek et al. [36], studying serum samples of 29 rheumatic patients (22 women and 7 men), reported that the concentrations of VCAM-1 increased significantly in rheumatoid patients' serum compared with healthy people.

Smith et al. [37] explored the impact of antirheumatoid therapies like MTX and others on patients having rheumatoid arthritis. That observed that the level 
of VCAM-1 decreased in the treated group of patients in comparison with the rheumatoid patients who had not been treating. Another study, whose results were contrary to our study's results, demonstrated that the adhesion molecules levels were lower in rheumatism patients in comparison with healthy people [38].

As regard the relationship between VCAM-1 concentration and age, period, and severity of the disease, the results of our study revealed significant differences between the three different age groups. However, our study did not reveal significant differences between the degrees (severe, moderate, and mild) of the disease severity. In addition, our results showed no significant differences between the first and second periods of the disease. The results of our current study agreed with the results of other studies which showed that there is no correlation between sex, age, disease period, and between the concentrations of adhesion molecules (VCAM-1, Intercellular adhesion molecule 1, E-selectin) and the VEGF [33], [38].

\section{Conclusion}

Our current study concludes that the concentrations of leptin in the serum were not affecting by the inflammatory state in patients with rheumatism. Concerning VCAM-1, we observed that disturbances in the VCAM-1 biomarker level for patients having rheumatism may be links to autoimmune diseases and inflammatory reactions. These increased levels of adhesion molecules can help predict therapeutic effects and can be used as a vital indicator for monitoring the disease.

\section{Acknowledgments}

Our thanks and appreciation to the department of biology and researchers in the physiological laboratory for postgraduate studies and Basrah general hospital for their support of our research.

\section{Ethics Approval and Consent to Participate}

This research was approved by the Basrah University - Iraq. Serum was obtained from patients at Basrah general hospital after their consent by filling out a questionnaire.

\section{References}

1. Santhosh TR, Moin A, Gowda DV, Abhilasha TP, Lakshmeesha $\mathrm{R}$, Patil NP, et al. Intra-articular drug delivery system for arthritic diseases: Overcoming the inadequacies of therapy. Indo Am J Pharm Res. 2016;6(1):4427-35. https://doi. org/10.1517/17425240802647259

PMid:19236205

2. Weinblatt ME, Kuritzky L. RAPID: Rheumatoid arthritis. J Fam Pract. 2007;56(Suppl 4):S1-7; quiz S8.

PMid:17403322

3. Carvalho AN, Firuzi O, Gama MJ, Horssen JV, Saso L. Oxidative stress and antioxidants in neurological diseases: Is there still hope? Curr Drug Targets. 2017;18(6):705-18. https://doi.org/10. 2174/1389450117666160401120514 PMid:27033198

4. Lago F, Dieguez C, Gómez-Reino J, Gualillo O. Adipokines as emerging mediators of immune response and inflammation. Nat Clin Pract Rheumatol. 2007;3(12):716-24. https://doi. org/10.1038/ncprheum0674

PMid:18037931

5. Faggioni R, Feingold KR, Grunfeld $\mathrm{C}$. Leptin regulation of the immune response and the immunodeficiency of malnutrition. FASEB J. 2001;15(14):2565-71. https://doi.org/10.1096/ fj.01-0431rev PMid:11726531

6. Otero M, Lago R, Lago F, Reino JJ, Gualillo O. Signalling pathway involved in nitric oxide synthase Type II activation in chondrocytes: Synergistic effect of leptin with interleukin-1. Arthritis Res Ther. 2005;7(3):R581-91. https://doi.org/10.1186/ ar1708

PMid:15899045

7. Toussirot E, Streit G, Wendling D. The contribution of adipose tissue and adipokines to inflammation in joint diseases. Curr Med Chem. 2007;14(10):1095-100. https://doi. org/10.2174/092986707780362826

PMid: 17456023

8. Golias C, Tsoutsi E, Matziridis A, Makridis P, Batistatou A, Charalabopoulos K. Review. Leukocyte and endothelial cell adhesion molecules in inflammation focusing on inflammatory heart disease. In Vivo. 2007;21(5):757-69.

PMid:18019409

9. Wong CW, Dye DE, Coombe DR. The role of immunoglobulin superfamily cell adhesion molecules in cancer metastasis. Int J Cell Biol. 2012;2012:340296. https://doi. org/10.1155/2012/340296

PMid:22272201

10. Sharma R, Sharma R, Khaket TP, Dutta C, Chakraborty B Mukherjee TK. Breast cancer metastasis: Putative therapeutic role of vascular cell adhesion molecule-1. Cell Oncol (Dordr). 2017;40(3):199-208. https://doi.org/10.1007/ s13402-017-0324-X

PMid:28534212

11. Allavena R, Noy S, Andrews M, Pullen N. CNS elevation of vascular and not mucosal addressin cell adhesion molecules in patients with multiple sclerosis. Am J Pathol. 2010;176(2):556-62. https://doi.org/10.2353/ajpath.2010.090437 PMid:20035048

12. Alexiou D, Karayiannakis AJ, Syrigos KN, Zbar A, Kremmyda A Bramis I, et al. Serum levels of E-selectin, ICAM-1 and VCAM-1 in colorectal cancer patients: Correlations with clinicopathological features, patient survival and tumour surgery. Eur J Cancer. 2001;37(18):2392-7. https://doi.org/10.1016/ s0959-8049(01)00318-5 


\section{PMid:11720833}

13. Yang ZX, Han ZB, Ji YR, Wang YW, Liang L, Chi Y, et al. CD106 identifies a subpopulation of mesenchymal stem cells with unique immunomodulatory properties. PLoS One. 2013;8(3):e59354. https://doi.org/10.1371/journal.pone.0059354 PMid:23555021

14. Folkman J Endogenous angiogenesis inhibitors. APMIS. 2004;112(7-8):496-507. https://doi. org/10.1111/j.1600-0463.2004.apm11207-0809.x PMid:15563312

15. Ding YB, Chen GY, Xia JG, Zang XW, Yang HY, Yang L. Association of VCAM-1 overexpression with oncogenesis, tumor angiogenesis and metastasis of gastric carcinoma. World J Gastroenterol. 2003;9(7):1409-14. https://doi.org/10.3748/ wjg.v9.i7.1409

PMid:12854131

16. Jhon RC. The ELISA Guide Book. Totowa, New Jersey: Humana Press Inc.; 2000. p. 26-8. https://doi.org/10.1385/1592590497

17. Wisłowska M, Rok M, Jaszczyk B, Stepień K, Cicha M. Serum leptin in rheumatoid arthritis. Rheumatol Int. 2007;27(10):947-54. https://doi.org/10.1007/s00296-007-0335-4

PMid:17443329

18. Bernotiene E, Palmer G, Gabay C. The role of leptin in innate and adaptive immune responses. Arthritis Res Ther. 2006;8(5):217. https://doi.org/10.1186/ar2004 PMid:16879738

19. Food and Drug Administration. Safety Update on TNF- $\alpha$ Antagonists: Infliximab and Etanercept. Silver Spring, Maryland: Food and Drug Administration, Center for Biologics Evaluation and Research. Arthritis Advisory Committee Meeting; 2001.

20. Popa C, Netea MG, Radstake TR, van Riel PL, Barrera $P$, van der Meer JW. Markers of inflammation are negatively correlated with serum leptin in rheumatoid arthritis. Ann Rheum Dis. 2005;64(8):1195-8. https://doi.org/10.1136/ ard.2004.032243

PMid:15731289

21. Hizmetli S, Kisa M, Gokalp N, Bakici MZ. Are plasma and synovial fluid leptin levels correlated with disease activity in rheumatoid arthritis? Rheumatol Int. 2007;27(4):335-8. https:// doi.org/10.1007/s00296-006-0264-7

PMid:17102942

22. Bokarewa M, Bokarew D, Hultgren O, Tarkowski A. Leptin consumption in the inflamed joints of patients with rheumatoid arthritis. Ann Rheum Dis. 2003;62(10):952-6. https://doi. org/10.1136/ard.62.10.952

PMid:12972473

23. Targońska-Stepniak B, Majdan M, Dryglewska M. Leptin serum levels in rheumatoid arthritis patients: Relation to disease duration and activity. Rheumatol Int. 2008;28(6):585-91. https:// doi.org/10.1007/s00296-007-0480-9

PMid:17968549

24. Toussirot E, Grandclément E, Gaugler B, Michel F, Wendling D, Saas $\mathrm{P}$, et al. Serum adipokines and adipose tissue distribution in rheumatoid arthritis and ankylosing spondylitis. A comparative study. Front Immunol. 2013;13(4):453. https://doi.org/10.3389/ fimmu.2013.00453

PMid:24379815

25. Tokarczyk-Knapik A, Nowicki M, Wyroślak J. The relation between plasma leptin concentration and body fat mass in patients with rheumatoid arthritis. Pol Arch Med Wewn. 2002;108(2):761-7

PMid:12476896

26. Salazar-Páramo M, González-Ortiz M, González-López L,
Sánchez-Ortiz A, Valera-González IC, Martínez-Abundis E, et al. Serum leptin levels in patients with rheumatoid arthritis. J Clin Rheumatol. 2001;7(1):57-9. https://doi. org/10.1097/00124743-200102000-00016

PMid:17039093

27. Buettner R, Bollheimer LC, Zietz B, Drobnik W, Lackner K, Schmitz G, et al. Definition and characterization of relative hypo- and hyperleptinemia in a large Caucasian population. J Endocrinol. 2002;175(3):745-56. https://doi.org/10.1677/ joe. 0.1750745

PMid: 12475385

28. Gunaydin R, Kaya T, Atay A, Olmez N, Hur A, Koseoglu M. Serum leptin levels in rheumatoid arthritis and relationship with disease activity. South Med J. 2006;99(10):1078-83. https://doi. org/10.1097/01.smj.0000240625.27772.79 PMid: 17100028

29. Abdalla M, Effat D, Sheta M, Hamed WE. Serum leptin levels in rheumatoid arthritis and relationship with disease activity. Egypt Rheumatol. 2014;36(1):1-5. https://doi.org/10.1016/j. ejr.2013.10.002

30. Mei H, Campbell JM, Paddock CM, Lertkiatmongkol $P$, Mosesson MW, Albrecht R, et al. Regulation of endothelial cell barrier function by antibody-driven affinity modulation of platelet endothelial cell adhesion molecule-1. J Biol Chem. 2014;289(30):20836-44. https://doi.org/10.1074/jbc. M114.557454

PMid:24936065

31. Harjunpää H, Llort Asens M, Guenther C, Fagerholm SC. Cell adhesion molecules and their roles and regulation in the immune and tumor microenvironment. Front Immunol. 2019;10:1078. https://doi.org/10.3389/fimmu.2019.01078

PMid:31231358

32. Navarro-Hernández RE, Oregon-Romero E, Vázquez-Del Mercado M, Rangel-Villalobos H, Palafox-Sánchez CA, MuñozValle JF. Expression of ICAM1 and VCAM1 serum levels in rheumatoid arthritis clinical activity. Association with genetic polymorphisms. Dis Markers. 2009;26(3):119-26. https://doi. org/10.3233/DMA-2009-0621

PMid:19597294

33. Klimiuk PA, Sierakowski S, Latosiewicz R, Cylwik JP, Cylwik B, Skowronski J, et al. Soluble adhesion molecules (ICAM-1, VCAM-1, and E-selectin) and vascular endothelial growth factor (VEGF) in patients with distinct variants of rheumatoid synovitis. Ann Rheum Dis. 2002;61(9):804-9. https://doi.org/10.1136/ ard.61.9.804 PMid:12176805

34. El-Miedany M, Ashour S, Moustafa H, Ahmed I. Altered levels of soluble adhesion molecules in patients with rheumatoid arthritis complicated by peripheral neuropathy. J Rheumatol. 2002;29(1):57-61.

PMid:11824972

35. Wang L, Ding Y, Guo X, Zhao Q. Role and mechanism of vascular cell adhesion molecule-1 in the development of rheumatoid arthritis. Exp Ther Med. 2015;10(3):1229-1233. https://doi.org/10.3892/etm.2015.2635 PMid:26622470

36. Klimek E, Skalska A, Kwaśny-Krochin B, Surdacki A, Sulicka J Korkosz $\mathrm{M}$, et al. Differential associations of inflammatory and endothelial biomarkers with disease activity in rheumatoid arthritis of short duration. Mediators Inflamm. 2014;2014:681635. https://doi.org/10.1155/2014/681635 PMid:24864133

37. Smith MD, Slavotinek J, Au V, Weedon H, Parker A, Coleman M, et al. Successful treatment of rheumatoid arthritis is associated with a reduction in synovial membrane cytokines and cell 
adhesion molecule expression. Rheumatol. 2001;40(9):965-77. https://doi.org/10.1093/rheumatology/40.9.965

PMid:11561106

38. Blann AD, Herrick A, Jayson Ml. Altered levels of soluble adhesion molecules in rheumatoid arthritis, vasculitis and systemic sclerosis. Br J Rheumatol. 1995;34(9):814-19. https:// doi.org/10.1093/rheumatology/34.9.814

PMid:7582719 